\title{
Incidence of Hepatitis C Infection among Multi-transfused $\beta$ - thalassemia Major Patients and its Correlation to Blood Groups in Amara City
}

\author{
Younus Jasim Abdullah*1, Nidhal Abdullah Hashim¹, Safaa M. Sultan² \\ \{younusjasim@stu.edu.iq ${ }^{1}$,nidhal.abdullah@stu.edu.iq², safaahawija@gmail.com³ \\ ${ }^{1}$ Southern Technical University, Amara Technical Institute. Amara city. Iraq \\ ${ }^{2}$ Northern Technical University, Mosul Medical Institute. Mosul city. Iraq
}

\begin{abstract}
Multi-transfused $\beta$ - thalassemia major patients still at high risk of acquiring blood-borne viruses just like hepatitis $\mathrm{C}(\mathrm{HCV})$, hepatitis B (HBV) and human immunodeficiency virus (HIV). To estimate the percent of HCV infection among multi-transfused $\beta$ - thalassemia major patients, a sample of (109) $\beta$ - thalassemia major patients were subjected to anti-HCV screening test using enzyme-linked fluorescent assay (ELFA) technique. The results revealed that $30(27.5 \%)$ patients present + anti-HCV in Amara city. However, the infection rate was higher in the male gender than females and increased with age. The results also found that $\mathrm{HCV}$ infection is predominant in $\mathrm{B}+$, $\mathrm{O}+$, and $\mathrm{A}+$ blood groups, moreover, a highly significant positive correlation detected between $\mathrm{HCV}$ infection and $\mathrm{B}+$ blood group.

The study concluded that there is an elevated rate of $\mathrm{HCV}$ infection among $\beta$ - thalassemia major patients, requiring more efficient viral screening techniques to the blood donors, the positive relationship between blood group and $\mathrm{HCV}$ infection suggests a role of gene-environment interaction and needing molecular studies to clarify such correlation.
\end{abstract}

Keywords: HCV. Thalassemia. Correlation. Blood Group.

\section{Introduction :}

Thalassemia is a diverse group of inherited diseases that occur as a result of synthesizing reduced amounts of globin, which is the major constituent of hemoglobin [1] (Najim, 2014). The disproportion synthesis of the globin chain leading to red corpuscle destruction in the marrow and circulation causing severe anemia. There are two different chains comprising hemoglobin molecule, $\alpha$, and $\beta$, and each could be influenced. Hence, thalassemia can be classified as $\alpha$-thalassemia and $\beta$ thalassemia (Abed, 2010).

Organized transfusion of blood to patients with the two types of thalassemia, has raised their survival, but represent a specific threat of acquiring blood-borne virus infection, particularly hepatitis $\mathrm{C}$ virus (HCV) and hepatitis B virus (HBV) (Bhavsar et al.,2011). Vaccination a giants HBV effectively limits the spreading of $\mathrm{HBV}$ infection, while, post-transfusion acquisition of $\mathrm{HCV}$ as yet a considerable health problem in thalassemia patients (Al-Naamani et al.,2015).

$\mathrm{HCV}$ is a member of RNA enveloped viruses, its genome composed of single-stranded positive-sense RNA and infect liver cells causing acute liver inflammation with prolonged complication and morbidity reached up to 3\% of all HCV patients. (Rosen, 2011).

The infection with $\mathrm{HCV}$ is responsible for about twenty percent of severe hepatitis, eighty percent of chronic hepatitis, forty percent of hepatic cell cirrhosis, seventy percent of hepatocellular carcinoma and thirty percent of liver transplantation (Rafiei et al.,2013). Also, it estimated that HCV causes high rates of liver infections to patients who have got blood transfusion before the uses of usual blood product screening tests (Hussain et al.,2008; Angelucci and Pilo, 2008).

During recent decades, the connection between various infectious diseases like hepatitis B and in hepatitis $\mathrm{C}$ and blood groups has been discussed with enthusiasm. It has been suggested that this connection may be due to interaction between microorganisms and red blood cell membrane, which can be justified by antigenic similarity, affinity to common receptors or antibody response deregulation (Pourhassan, 2014). 
In Iraq, several studies have screened the prevalence of $\mathrm{HCV}, \mathrm{HBV}$ and human immunodeficiency virus (HIV) among $\beta$ - thalassemia major patients all over the country, and the results were varied according to the study population, method of virus diagnosis as well as resident habits. However, few studies found to detect the relevance between blood groups and HCV infection among $\beta$ - thalassemia major patients, so the current study aimed to find out such relation, as well as, to clarify the relation between $\mathrm{HCV}$-infection among $\beta$ - thalassemia major patients with other sociodemographic factors

\section{Materials and Methods:}

\subsection{Study population and Specimens:}

The present study involved (109) people suffering from $\beta$ - thalassemia major, who registered in Thalassemia Center in Amara city during the period from Apr. 2017 to Oct. 2017. Their ages were (2-37 years old) and from both genders. All of them have received blood transfusion one time monthly. Other sociodemographic factors are seen in (Table 1).

Table 1: Demographic and Genetic features of $\beta$ - thalassemia major patients.

\begin{tabular}{ccc}
\hline Characteristics & No. of Patients $(\mathbf{n o}=\mathbf{1 0 9})$ & Percentage \\
\hline Male & Gender & $\mathbf{5 9 . 6}$ \\
Female & 44 & $\mathbf{4 0 . 4}$ \\
& Age groups & \\
2-6 years & 23 & $\mathbf{2 1 . 1}$ \\
7-11 years & 24 & $\mathbf{2 2 . 0 1}$ \\
12-16 years & 25 & $\mathbf{2 2 . 9 3}$ \\
More than 17 years & 37 & $\mathbf{3 3 . 9 4}$ \\
Yes & Undergo Splenectomy & \\
No & 44 & $\mathbf{4 0 . 4}$ \\
& 65 & $\mathbf{5 9 . 6}$ \\
Positive Family History & Genetic Characteristics & $\mathbf{4 6 . 7 8}$ \\
Parents Relative & 51 & $\mathbf{8 8 . 9 9}$ \\
\hline
\end{tabular}

\subsection{Blood Collection and Serum Preparation:}

$3 \mathrm{ml}$ of venous blood were collected from all patients in gel tubes then centrifuged $(5000 \mathrm{rpm} /$ 5 mints) and the obtained sera were used for the diagnosis of Anti-HCV antibodies using VIDAS tools.

\subsection{HCV diagnosis:}

Anti-HCV antibodies were screened in serum samples from children with $\beta$ - thalassemia major by the techniques of ELFA (Enzyme-Linked Fluorescent assay) using VIDAS anti-HCV kit performed by ( Biomerieux France, 2017).

\subsection{Ethical clearance:}

Permission to conduct this study was issued by the Health institutional and the collection of Blood samples of individuals was carried out by under public health technician supervision.

\subsection{Statistics:}


The data were entered and analyzed using the Spss tool ver. 20 software. Percentage, Chi-square, and Pearson Correlation Test were applied to examine the results of this study. P-value (0.05) was considered statistically significant.

\section{Results:}

The results of the current study found that 30 people $(27.5 \%)$ of $\beta$ - thalassemia major patients presents Anti-HCV antibodies as shown in (Table 2). Out of the $30 \mathrm{HCV}$-infected, $22(73.3 \%)$ are males and $8(26.7 \%)$ are females. Also, the percentage of HCV infections increases with age to reach $(50 \%)$ in the age group (mo3re than 17 years). Also, it is found that HCV infection is higher in patients that have undergone splenectomy, with a positive family history of thalassemia and patients who were born to parents relatives, (Table 3 ).

Table 2: Prevalence of Anti-HCV antibodies among $\beta$-thalassemia major patients.

\begin{tabular}{ccc}
\hline Characteristics & No. of Patients $($ no= 109) & Percentage \\
\hline \multirow{3}{*}{ Yes } & Anti-HCV Antibodies \\
No & 30 & $\mathbf{2 7 . 5}$ \\
& 65 & $\mathbf{7 2 . 5}$ \\
\hline
\end{tabular}

Table 3: Demographic and Genetic characteristics of HCV-infected $\beta$ - thalassemia major patients.

\begin{tabular}{cccc}
\hline Characteristics & No. of Patients $(\mathbf{n o = 1 0 9})$ & Percentage & Significance \\
\hline Male & Gender & 73.3 & N.S \\
Female & 22 & 26.7 & \\
& 8 & & N.S \\
$2-6$ years & Age groups & 6.67 & \\
7-11 years & 2 & 16.66 & \\
12-16 years & 5 & 26.67 & \\
More than 17 years & 8 & 50 & N.S \\
Yes & 15 & 56.7 & \\
No & Undergo Splenectomy & 43.3 & N.S \\
Positive Family History & 17 & 53.33 & \\
Parents Relative & Genetic Characteristics & 90 & \\
\hline
\end{tabular}

The relevance between blood groups and HCV infection in $\beta$ - thalassemia major subjects were estimated in the present study and the results showed, as seen in (Table 4), that HCV is more common among patients of $(\mathrm{B}+, \mathrm{O}+$, and $\mathrm{A}+)$ blood groups respectively, while, no $\mathrm{HCV}$ infections were found in patients of (A-, B- and AB- ) blood groups. Besides, a positive high significant relationship was found between subjects of $(\mathrm{B}+)$ blood group only and HCV infection, when tested by Pearson Correlation Test, other blood groups excluding $\mathrm{O}+$ were negatively correlated with HCV infections, (Table 5).

Table 4: Percentages of HCV infections among blood groups of $\beta$ - thalassemia major patients.

\begin{tabular}{cclc}
\hline Blood groups & Frequency & Percent & Cumulative Percent \\
\hline B+ & 13 & 43.3 & 66.7 \\
O+ & 8 & 26.7 & 100 \\
A+ & 6 & 20 & 20 \\
O- & 2 & 6.7 & 73.3 \\
AB+ & 1 & 3.3 & 23.3 \\
\hline \hline
\end{tabular}


Table 5: Pearson Correlation Test of blood groups and HCV infection

\begin{tabular}{|c|c|c|c|c|c|c|c|c|c|}
\hline Correlations & $\mathrm{HCV}$ & $\mathrm{A}+$ & A- & $\mathrm{B}+$ & B- & $\mathrm{AB}+$ & AB- & $\mathrm{O}+$ & O- \\
\hline $\begin{array}{c}\text { Pearson } \\
\text { Correlation }\end{array}$ & 1 & $-.069-$ & $-.118-$ & $.219^{*}$ & $-.118-$ & -.033- & $-.082-$ & $-.034-$ & .037 \\
\hline Sig. (2-tailed) & & .477 & .224 & .022 & .224 & .735 & .395 & .729 & .704 \\
\hline $\mathrm{N}$ & 109 & 109 & 109 & 109 & 109 & 109 & 109 & 109 & 109 \\
\hline
\end{tabular}

*. Correlation is significant at the 0.01 level (1-tailed).

\section{Discussion:}

As stated above, $\mathrm{HCV}$ infects $(27.5 \%)$ of $\beta$ - thalassemia major patients involved in the current study, which is the latest one in Amara city, south of Iraq.

Generally, the rate of anti-HCV among Iraqi $\beta$ - thalassemia major subjects are ranging between $(10.4 \%)$ in the north, $(19.9 \%)$ in the middle and $(19 \%)$ in the south (Khaled, 2014; Albahadle et al.,2013; Hashim et al.,2013). The higher rate of infection detected in the current study indicates increasing viral contamination in blood units transfused to $\beta$ - thalassemia major patients, which is considered the major risk factor for acquiring an $\mathrm{HCV}$ infection, requiring a more effective viral screening test to the blood donors (AL-Juboori, 2012).

Furthermore, in Iraq patients with $\beta$ - thalassemia major has a higher infection rate in comparison with Niebuhr countries such as Iran 12.5\% (Borouerdnia et al.,2009), Saudi Arabia and Kuwait $18 \%$ and $5.7 \%$ respectively (Fallahian and Najafi, 2011). Remarkably, variations in the study population and the development in blood donor screening tests with restrictive policy in other states might be led to decreased incidence than those reported in our study.

According to (Table 3 ) it is clear that HCV infects $\beta$ - thalassemia major males more than females, the incidence of infection increases with the age, the infection is higher in patients that undergone splenectomy and in patients with positive family history of thalassemia in addition to those how were born from parents relatives, but no significant association detected between HCV infection and any of the sociodemographic factors stated above.

A wide range of $\mathrm{HCV}$ infection among $\beta$ - thalassemia major patients were detected word wide. This range is varied significantly between countries and between thalassemia centers in the same country according to several factors such as the health standards of a country and cultural awareness among residents (W.H.O, 2010; Katsanos et al.,2005).

Studies found a significant and non-significant association between sociodemographic characters and HCV infection in $\beta$ - thalassemia major patients, however, most studies concluded that males, according to lifestyle, are at high risk than females to be $\beta$ - thalassemia major, hence, they are at high risk to receive bloodborne infection like HCV. Studies also concluded that the rate of infection increases with the age and there is a significant association of HCV infection and splenectomy. The differences between studies may have resulted from the difference in assay system used for diagnosis of HCV infection and incidence of HCV antibodies in the healthy persons and, in a small extent, the bad habits of residents, (Ataei et al.,2012; Tamaddoni et al.,2007).

Results of tables (4 and 5) revealed that HCV infection is more prevalent in some blood groups than others, also, a positive significant correlation was found between infection and (B+) blood group. Similarly, a study achieved in Al-Najaf Al-Ashraf governorate noticed that patients of O+ blood group represented the higher seropositivity to anti $-\mathrm{HCV}$ than patients with other blood groups, however patients with Rh- shows lower seropositivity to anti-HCV (Abd, 2012). Also, HCV found to infects (41.667\%) of $\mathrm{O}+$ healthy blood donors in Baghdad (Aljooani et al.,2012), whereas, in Iran, anti$\mathrm{HCV}$ is more prevalent in patients of $\mathrm{B}+$ and $\mathrm{O}+$ blood groups followed by blood group $\mathrm{A}+(\mathrm{Naeini}$ et al.,2010).

Gene-environment interaction might explain the association of blood groups with the incidence of certain diseases like HCV. Blood groups are carbohydrate molecules that are determined genetically and presented on the membranes of red blood corpuscles where function as receptors or ligands for bacteria, parasites, and viruses. These molecules are known to show relevance with different contagious and noninfectious diseases (Das and Kimar, 2012). Thus, it is discovered that type O blood group having nearly twice the incidence of duodenal ulcer caused by Helicobacter pylori than the two types A and B. In addition, persons with A blood group show a high incidence of tumors of salivary glands, stomach, and pancreas (Anstee,2010). 
On the other hand, the overall incidence of $\mathrm{ABO}$ groups in the resident population and either is the most predominant could affect the incidence of HCV in a certain country. In this context, the dominant blood groups in Amara city are $\mathrm{O}+$ then $\mathrm{B}+$ and $\mathrm{A}+$ (Mahaus et al.,2010).

Over and above, the gene-environment interaction may be a good explanation for the incidence of anti$\mathrm{HCV}$ and other infectious diseases among certain blood groups.

\section{Conclusions:}

Anti-HCV found in $(27.5 \%)$ of multi-transfused $\beta$ - thalassemia major patients, the percent of infection is higher than previous studies, suggesting increasing viral contamination of blood units transfused to patients requesting efficient viral screening test to the blood donors. Anti-HCV incidence is prevalent among patients of $(\mathrm{B}+, \mathrm{O}+$, and $\mathrm{A}+$ ) blood groups respectively with no incidence of Rh- groups. Also, a positive significant correlation found between the prevalence of anti$\mathrm{HCV}$ and $\mathrm{B}+$ groups, suggesting the role of gene-environment interaction.

\section{Acknowledgment:}

The authors would like to thank the manager of the main blood bank in Maysan city, Hassan Rahman Shawy, and the professor. Dr. Wathiq Ayoub Taha Al-Ramadhan, the Dean of Basrah Technical Institute, for their assessment in obtaining samples and supporting the current study.

\section{Conflict of interest}

All authors of the current study declare that there is no conflict of interest

\section{References}

[1] Abd MH.. Factors affecting Transmission of Hepatitis C Among The Thalassemia Patients in Al_Najaf AlAshraf Governorate. Iraqi Board Thesis, College of Medicine, University of Kufa, Al_Najaf Al-Ashraf. Iraq (2012).

[2] Abed BA.. Prevalence of hepatitis C virus (HCV) among thalassemia patients in Ibn-ALbalady hospital. Journal of Al-Nahrain University; 13(1): 121-126. (2010)

[3] Albahadle AJ, Abass AA and Ali AH.. Prevalence of hepatitis C infection among multitransfused thalassemia major patients in Ibn-Albalady Center of thalassemia; Q. M. J.; 9(15): 73-84. (2013)

[4]Aljooani O, Al-Hayani $\mathrm{N}$ and Mohammed M. The infection with $\mathrm{HBV}$ and $\mathrm{HCV}$ and their relation to $\mathrm{ABO}$ blood group among blood donors. Fac. Med. Baghdad; 54(1): 52-52. (2012).

[5] Al-Juboori LF.. Hepatitis C virus in thalassemia patients in Tikrit. Tikrit Medical Journal; 18(1): 95-100. (2012)

[6] Al-Naamani K, Al-Zakwani I, Al-Sinani S, Wasim F and Daar S. Prevalence of hepatitis C among multitransfused thalassemic patients in Oman. Sultan Qaboos University Med. J,; 15(1): 46-51. (2015).

[7] Angelucci E and Pilo F. (2008). Treatment of hepayitis C in patients with thalassemia. Haematologica; 93(8): $1121-1123$

[8] Anstee DJ. The relationship between blood groups and disease. Blood; 115(23): 4635-4643. (2010).

[9] Ataei B, Hashemipour M, Kassaian N, Hassannejad R, Nokhodian Z and Adibi P.. Prevalence of anti-HCV infection in patients with beta-thalassemia in Isfahan-Iran. I. J. P. M.; special issue: s118-s123. (2012)

[10] Bhavsar H, Pate K, Vagad M, Madan M, Pandey A, Asthana A and Mistry K. Prevalence of HIV, hepatitis B and hepatitis $\mathrm{C}$ infection in thalassemia major patients in tertiary care hospital, Gujarat. N.J.R.M.; 2(3): 47-50. (2011).

[11] Borouerdnia MH, Zadegan MA, Zanadian KM and Rodan MH. Prevalence of hepatitis-C virus (HCV) among thalassemia patients in Khuzestan province, Southwest Iran. Pak. J. Med. Sci.; 25(1): 113-117(2009).

[12] Das s and Kimar ML. Association of blood group types to hepatitis B and hepatitis C virus infection among blood donors- a five years institutional based study. International Journal of Basic Science; 2(1): 191-195. (2012).

[13] Fallahian F and Najafi A. Epidemiology of hepatitis C in middle east. Saudi. J. Kidney Dis. Transplant.; 22(1): 1-9. (2011).

[14] Hashim NA, Abdolreza ZA, Taan KH and Adolhussain A. Prevalence of hepatitis C virus among thalassemia patients in Maysan governorate. Al-Mustansiriyah Journal of Science; 24(3): 51-56. (2013).

[15] Hussain H Iqbal R, Khan MH, Iftikhar B, Aziz S, Burki FK, Sethi J, Hassan M, Nisar Y and Krishan J.. Prevalence of hepatitis C in beta thalassemia major. Gomal Journal of Medical Science; 6(2): 87-90. (2008).

[16] Katsanos KH, Chaidos A, Christodoulou DK, Tzamborous N, Zervou E, Bourandas KL and Tsinos EV. Epidemiology and clinical characteristics of HCV infection in transfusion-dependent thalassemia. Annals of Gastroenterology; 18(1): 56-64.( 2005). 
[17] Khaled MD. Prevalence of hepatitis B, hepatitis C and human immunodeficiency virus infection among Thalassemia patients in Ninavha Governorate/Iraq. Journal of Biotechnology Research Center (Special Edition); 8(2): 11-13. (2014).

[18] Pourhassan, Abolfazl. "Association between ABO blood/rhesus grouping and hepatitis B and C: a casecontrol study." Pak J Biol Sci 17.6 (2014): 868-71. 